\title{
Beyond Repair: \\ Interpretation, Reparation, and Melanie Klein's Clinical Play-Technique
}

"Who, for example, decides what constitutes a problem for the patient? And by what criteria?" —Adam Phillips, "Keeping It Moving"

In 2003, Eve Kosofsky Sedgwick published the final version of her wittily-titled essay, "Paranoid Reading and Reparative Reading, Or You're So Paranoid, You Probably Think This Essay Is About You," in Touching Feeling: Affect, Pedagogy, Performativity, issuing what would become an influential call for alternative critical methodologies for queer, feminist, and LGBT scholarship. In this essay, Sedgwick diagnoses the current hegemony of what she hails as "paranoid reading," a method of reading that creates a climate of internecine hostility by fostering a relation of suspicion, antagonism, and anticipatory anxiety between the critic and her object. Aligning paranoia with the decades-past critical practice of symptomatic interpretation, ideology critique, and demystification, Sedgwick proposes instead a "reparative reading" that would forego the distant, omniscient, aggressive and hostile attitude of former methods and replace them with strategies of love, nurture, intimacy, and repair. Sedgwick culls the terms that organize her diagnosis of critical methods_-"paranoia" and "reparation"-from Melanie Klein's psychoanalytic theory of the paranoid-schizoid and depressive positions, taking what Klein theorized as the subject's oscillating (and unconscious) object relational positions and turning them into consciously orchestrated critical methodologies. It remains an enduring irony of this essay that Sedgwick used Klein's psychoanalytic concept of reparation to enact a departure precisely from psychoanalytic ("symptomatic") methods of reading themselves. As this article discusses, the ethical stakes of this deployment are pronounced by returning to Klein's clinical writings about child analysis, the trademark of which was Klein's zealous reliance on the curative potential of interpretive practice.

In one of the most heavily cited passages from Sedgwick's text, she elaborates her alternative "reparative" methodology as follows:

To read from a reparative position is to surrender the knowing, anxious paranoid determination that no horror, however apparently unthinkable, shall ever come to the reader as new; to a reparatively positioned reader, it can seem realistic and necessary to experience 
surprise. Because there can be terrible surprises, however, there can also be good ones. Hope, often fracturing, even a traumatic thing to experience, is among the energies by which the reparatively positioned reader tries to organize the fragments and part-objects she encounters or creates. Because the reader has room to realize that the future might be different from the present, it is also possible for her to entertain such profoundly painful, profoundly relieving, ethically crucial possibilities as that the past, in turn, could have happened differently from the way it actually did. (2003, pg. 146)

Although Sedgwick is clear that the purpose of her intervention is not to unilaterally eliminate all "paranoid" reading practices in favor of their reparative counterparts but rather to open the field of critical practice to multiple (equally legitimate) methods of reading, she does still attribute a moral superiority to reparativity, saying that "it will leave us in a vastly better position to do justice to a wealth of characteristic, culturally central practices" (2003, pg. 147). To read reparatively, Sedgwick suggests, is to act on behalf of the object's own good, to "assemble and confer plenitude" on the object as a way of sustaining the self (2003, pg. 149). Juxtaposed against the less enlivening "paranoid position" (Sedgwick describes this position as "cruel," “contemptuous," "ugly," "grim," "strong," “monopolistic," "normative," "cynical," and "triumphalist"-all in just two pages), the ethical heft of the reparativity resides in its ability to (nonviolently) assess the dimensions of the object's injury and proffer adequate restitution (2003, pg. 143-44). For Sedgwick, reparativity imagines a reciprocal relation in which the act of sustaining one's self also seamlessly sustains the object.

Sedgwick's methodological proposition has been a generative one for queer theory, feminist theory, affect theory, and literary studies generally with scholars taking up the "reparative turn" both as a stylistic for reading and as an object in and of itself. José Muñoz (2006), Heather Love (2007), Elizabeth Freeman (2010), Ellis Hanson (2011), Ann Cvetkovitch (2012), Robyn Wiegman (2014), Clare Hemmings (2014), Gail Lewis (2014), Jackie Stacy (2014), and David Eng (2016) have all participated in the conversation about reparative reading, sometimes enacting and sometimes critiquing it. Love employs a reparative method in order to "feel backward," to reclaim the ephemera of a lost queer past that 
assimilationist progress narratives have strategically disavowed; Cvetkovitch finds reparativity to be a vital tool for generating narratives about depression in the present that resist the monopolizing undertow of medicalization; Hanson situates reparativity between queer negativity and affirmationist queer crip theory through a reading of Gary Fisher; Wiegman offers a reparative address to her mother by unfurling the place of critic's desires in a method that aims to do justice to the object; Lewis queries Wiegman's critique of reparativity by turning to post-Kleinian psychoanalysts Wilfred Bion and Christopher Bollas who underscore the importance of interpersonal connection in reparative relations; and Eng interrogates the political history of reparations to theorize the way that colonialism has resulted in an uneven distribution of affect and reason. These feminist and queer scholars join a wider movement across the humanities that has searched for a "post-critical" method of reading since the mid-2000s. Affect theory, systems and network theories, cultural anthropology, various visual and quantitative new media approaches, and literary studies have all housed debates about method, albeit under diverse banners like "distance reading," "surface reading," and "thin description." For all of these scholars, the question of critical method, especially as animated by a concern for ethical forms of relation between critic and her object, proves a significant, present tense concern for the way they narrate both past and future. ${ }^{1}$

This article begins with the recognition that both clinical psychoanalysis and critical inquiry share an abiding investment in questions of method, and from this suggests that Klein's clinical writings about child analysis are relevant and necessary to the current debates about reparativity and critical method in queer and feminist theory. Taking Klein's writing about clinical technique as my object, I first unpack the under-acknowledged importance of interpretation in the Kleinian clinic. Unlike those critics who have turned to reparativity, Klein herself relied on a dramatic, almost fantastical, style of interpretation that read children's play to its limits in order to palliate their symptoms and in so doing raised questions about

\footnotetext{
${ }^{1}$ For the purposes of this article, my scope is limited to those, following Sedgwick, who work explicitly within the framework of "reparative reading." However, other key contributors to the debates about critical method include Steven Marcus and Sharon Best, Rita Felski, Ellen Rooney, Franco Moretti and Toril Moi, as well as a number of special issues of journals such as Novel (2009), Representations (2009), differences (2010), SAQ (2011), GLQ (2011), M/C Journal (2012), Feminist Theory (2014), amongst others.
} 
the potential (in)separability of aggression from reparation, of destructiveness from creativity. These concerns, especially as they have to do with the ethical status of reparation, are well exemplified by Klein's lengthy 1941 case study of "Richard," a young boy fascinated by the wartime politics of attack and reparation. I argue that Richard's play, his clinical "war games," and Klein's interpretations of them pronounce some of the ethico-political dangers inherent in reparative endeavors, which name the object and narrate its injury according only to the perimeters of one's own self. As I demonstrate, reparation in Klein's oeuvre is far more fraught than recent mobilizations of it as "reparative reading" suggest; while it may imbue the (child) subject with the feeling of ethical action, this subjective feeling has little to do with the status of the object as the (potentially unwilling) recipient of such assignations of injury and repair. What, I ask, changes in our understanding of reparation if we switch the focus from the child's own good feeling to the political status of the objects to which it attaches? How might this change in focus highlight some of the ethical problems inherent in a method implicitly that strives to do good through processes of identification? With these questions in mind, I ultimately propose that the concept of reparation might be useful not as an ethical ideal (methodologically or otherwise), but as a way of naming the limits of our ability to ever fully know or act on behalf of the object's own good, be it a text, a patient, a social group, or an object. In this way, Kleinian reparation marks the inseparability of the ethical from the political and invites a more critical consideration of the necessary but interminable work of struggling to realize justice in and through relationality. By returning reparativity to Klein, I thus aim not to offer a corrective to Sedgwick or to the scholars following her, but to suggest the utility of clinical writing for critical thought, especially when it comes to the reparative ethics of interpretive practice. $^{2}$

\footnotetext{
${ }^{2}$ My decision to read Klein's theory of reparation specifically, separated from later interpreters like Wilfred Bion, Elizabeth Bott Spillius, Hannah Segal, R.D. Hinshelwood, or Donald Meltzer, has to do with historical methodology organizing this paper. Because reparative reading practices were catalyzed by Eve Kosofsky Sedgwick's engagement with Klein, I think a detailed return to Klein's original theory and socio-political context is not only lacking from current scholarship on reparative reading, but also (and more importantly). For a recent use of specifically post-Kleinian theories of reparation to consider reparative reading, see Gail Lewis's "Not by Criticality Alone" (2014).
} 


\section{Child's Play: Klein's Clinical Technique}

Melanie Klein (née Reizes) was born in Vienna in 1882 to Jewish parents, the youngest of four children. Her early life was strained by her family's intermittent insolvency and by her elder brother's chronic illness (tuberculosis), from which he died in 1902. Klein would not become a recognized figure in the psychoanalytic community until over 20 years later when, with the support of her analyst Karl Abraham and the help of Ernest Jones, she emigrated to London permanently and became not only one of the founders of child psychoanalysis and the first European member of the British Psychoanalytic Society (BPS), but also one of the most significant authorities on psychoanalytic theory and practice after Sigmund Freud's death in 1939. Her work with children throughout the 1930s, 40s, and 50s established the field of "Object Relations" and inaugurated one of the most significant post-Freudian psychoanalytic orientations to date. ${ }^{3}$

Influential though Klein's work undoubtedly was, her rise to prominence was dogged by constant criticism about the questionable orthodoxy of her interpretations of Sigmund Freud's work. These contestations were perhaps best exemplified in the series of debates held by the BPS from 1941-46, aptly named the "Controversial Discussions." Anna Freud especially took issue with many aspects of Klein's thinking, not the least of which was Klein's highly interpretive clinical technique with children. Because Sigmund Freud designed his clinical technique — the "talking cure"-for adults, much of the debate between Anna Freud and Klein centered on what kinds of modifications (if any) the analyst ought to make in order to analyze children. For her own part, Klein maintained that her clinical treatment of children strictly adhered to the classical method that Sigmund Freud laid out. The analyst's job, in her paradigm, was to create conditions that facilitated the child's transference, which the analyst would then

\footnotetext{
${ }^{3}$ For a comprehensive biography of Melanie Klein's life and work, see Phyllis Grosskurth's Melanie Klein: Her World and Her Work (1986).

${ }^{4}$ For a full accounting of these discussions, see Pearl King and Ricardo Steiner's The Freud-Klein Controversies, 1941-45. For cultural studies analyses of these discussions, see Jacqueline Rose's "War in the Nursery" in her Why War? - Psychoanalysis, Politics, and the Return to Melanie Klein and Deborah Britzman's After Education: Anna Freud, Melanie Klein, and Psychoanalytic Histories.
} 
verbally interpret in order to lessen the child's resistance and alleviate its anxiety. Since this technique gave priority to interpretation and transference, both hallmarks of Sigmund Freud's original method, Klein fervently defended the orthodoxy of her approach.

Yet, in spite of Klein's adamant assertion that there is a fundamental similarity between child analysis and adult analysis, she did have to implement one noteworthy modification for the analysis of child patients: Klein's most frequent interpretations were not of words but of actions. Given that Klein often worked with children either too young to speak or whose speech was strongly inhibited, most of her clinical interpretations relied on what children did with their hands rather than with their mouths. Instead of listening to the (adult) patient's speech, Klein observed the (child) patient's play, rendering her verbal interpretations from their physical manipulation of objects. "Children," argues Klein, "substitute actions (which were the original precursors of thoughts) for words: with children, acting plays a prominent part" (Klein, 1926, pg.135). According to Klein, acting not only plays a prominent part, but playing acts as a due substitution for speech. Klein's conviction about the unimpeachable orthodoxy of her method rests on her belief in the fundamental substitutability of words for actions, of word play for child's play, a conviction that raises interesting questions about exactly what kind of "act" speech is to being with. Both word play and child's play, Klein argues, are forms of free association.

Klein ensured this ostensible "freeness" by furnishing her child patients with a panoply of toys consciously cultivated to match what she understood to be their unconscious needs:

Their smallness, their number and their great variety give the child a wide range of representational play, while their very simplicity enables them to be put to the most varied uses. Thus toys like these are well suited for the expression of phantasies and experiences in all kinds of ways and in great detail. (1932, pg.32-33)

Although children were allowed to bring their own toys, as Klein notes above, she also provided a curated selection of objects for the child. The array of small, simple toys included figures of cars, people, houses, animals, trees, and carts. To the extent that play operates as symbolic language in Klein's play technique, the provision of toys is roughly equivalent to the provision of the words the child can use throughout the 
sessions. Klein's choice of objects—-small or large, geometric or organic, neutral or brightly colored, damaged or fully functioning - already determines the symbolic capacity of the child's play. For instance, driven by her sense of which phantasies predominate in the child's mind, Klein repeatedly asserts that the child should also have access to running water specifically because many oral and urethral phantasies are represented through this medium.

Reflecting on the clinical modifications that she implemented for these child patients, Klein nevertheless defends her play-technique as entirely consistent with the fundamentals of a "classical" method. "Just as children's means of expression differ from those of adults so the analytic situation in the analysis of children appears to be entirely different. It is, however, in both cases essentially the same" (1926, pg.137). What Klein suggests here is that the clinical substitution of objects for words is, if not unimportant, then a matter of only_and literally_technical difference: "[i]t is a question only of a different technique, not of the principles of treatment" (ibid, emphasis added, pg.138). Klein insists that any differences manifested by her play technique are mere technicalities: issues of negligible importance that do not disrupt the more fundamental "principles of treatment."

Readers of Klein's work have ample opportunity to see demonstrations of this interpretive playtechnique since, perhaps more than any other analyst, Klein employed clinical case material to exemplify her theories. Take, for instance, this short clinical vignette from Klein's first monograph, The Psychoanalysis of Children (1932). This passage records Klein's interpretations of her patient, Peter, “an extremely timid, plaintive and unboyish child" of three years and nine months old who came to Klein for a prophylactic analysis (ibid, 16). Peter played with Klein's toys and in, the course of one of his games, Klein offers the following interpretation:

Once, when he had put the motor-cars, which symbolized his father's penis, in a row side by side and had made them run along, he lost his temper and threw them all about the room, saying: 'We always smash our Christmas presents straight away; we don’t want any.' Smashing his toys thus stood in his unconscious for smashing his father's genitals. This pleasure in destruction and inhibition in play, which he brought into his analysis, were 
gradually overcome and disappeared together with his other difficulties during the course of it. (Ibid, pg. 20-21)

Here, Klein reads Peter's fit of rage as a destructive attack aimed not at the toys themselves, but at his father's penis and offers an apparently curative interpretation. If the equation of motorcars with Peter's father's penis seems pellucid to Klein, it likely raises more than a few questions readers who are not given any explanations for this abrupt comparison. How, for instance, did Klein establish the symbolic capacity of the toy car? How much does Peter know about his father's genitals? What are the perimeters of the analyst's interpretations and according what criteria would their accuracy be validated?

These questions were all the more pressing given Klein's capacity to push interpretation to its limits, testing the threshold of the plausible when it came to even the most quotidian actions. Klein's answer to these concerns comes in the form of a unique theory about children's psychic life. Working against developmental models of mind (such as Anna Freud's), Klein considered even the smallest infant to be a temporally complex organism, riven by conflicted phylogenetically inherent biological instincts that motored the child's unconscious phantasies. Klein draws much of her thinking about unconscious phantasy from a biologistic understanding of phylogenesis and narrates the unconscious phantasies of the child (and adult) according to the instinctual inheritance of the past. Although it is often overlooked in scholarship on Klein that pits "object relations" squarely against "instinct" or "drive" theory, Klein's theory of unconscious phantasy is actually deeply invested in the interaction between the life and death instincts. Unlike Freud who often used 'trieb' (drive) instead of 'instinkt' (instinct), Klein relies heavily on the latter term both in German and in English (almost all of her post-1920s writing was in English). In short, Klein's account of unconscious phantasy—a concept central to her unique theory of subjectivityis determined by the body's instincts and their vicissitudes. ${ }^{5}$

\footnotetext{
${ }^{5}$ For further reading on the role of instinct in Klein's theory of unconscious phantasy, see Susan Isaacs 1943 paper on "The Nature and Function of Phantasy" and R.D. Hinshelwood's definition of the same term in A Dictionary of Kleinian Thought (34). For a recent analysis of the elision of Klein's biologism from feminist readings of her work, see Elizabeth A. Wilson's Gut Feminism (2015).
} 
So, when prompted to account for how a child of two or three years old could be made ill by unconscious phantasies about specific sexual acts or body parts with which it has had little experience (such as its father's penis, its mother's vagina, the "combined parent" figure copulating, and its own internal children), Klein replies that these phantasies are the product of an instinctual species inheritance, which (in)forms the child's unconscious. "Even the quite small child," writes Klein, "which seemingly knows nothing about birth, has a very distinct unconscious knowledge of the fact that children grow in the mother's womb" (Klein, 1927, pg.173). Endowed with this unconscious, instinctual knowledge, children "represent symbolically phantasies, wishes and experiences [in their play]. Here they are employing the same phylogenetically acquired mode of expression as we are familiar with from dreams" (Klein, 1926, pg.134). In other words, the child comes into the world with an instinctual world of its own. Its mind is prepopulated by phantasies that stem from somatic origins and instinctual inheritances, which the child then acts out in the symbolic realm of play. If Sigmund Freud's work upended developmental temporality by emphasizing the determinative importance of childhood experiences in the psychic life of the adult, then Klein's child analysis flipped this equation, highlighting the incredible (almost unbelievable) psychical sophistication of an infant no more than six months old.

Klein never discusses exactly which phantasies and symbols she understands to be phylogenetically transmitted and why, a refusal that again left many of her more socially-minded critics in the dark about how she arrived at her seemingly "wild" interpretations, especially when they catalyzed not relief but resistance in the child-patient. Anna Freud, in her own critique of Klein's technique, raises these concerns in a not-inaccurate pantomime of Klein's interpretations. "If the child overturns a lamppost or a toy figure," hypothesizes Anna Freud,

she [Klein] interprets this action, e.g., as an aggressive impulse against the father; a deliberate collision between two cars as evidence of an observation of sexual union between the parents. Her procedure consists in accompanying the child's activities with translations and interpretations, which themselves - like the interpretations of the adult's free associations — exert a further influence on the patient. (Freud, 1927, pg.37)

Please DO NOT DISTRIBUTE: Forthcoming at Studies in Gender and Sexuality 
While Klein accused Anna Freud of embodying an undue pedagogical authority that bullied the patient into compliance, Anna Freud shoots back that Klein's "classical” interpretations are no less coercive. In the end, Anna Freud's point is not simply that Klein gets her interpretations wrong, (although there is a tacit accusation of "wild analysis" at work in Anna Freud's remarks), but rather that Klein's interpretive method is not nearly as neutral and benign as she might suggest. Through baroque interpretation, Klein "exert[s] a further influence on the patient," crossing the line from interpretation to out-and-out suggestion.

Part of what Anna Freud is drawing attention to here, therefore, is the ethical dimension of interpretation in clinical psychoanalysis, which in Klein's case could be read as bleeding into "suggestion," or a kind of intervention that exercises the analyst's own ideology rather than exorcising the patient's unconscious phantasies. This is a significant, if somewhat impossible, problematic since the line separating "suggestion" from "interpretation" might generously be called incoherent, especially given that the only potential arbiters are enveloped in the counter/transference. Indeed, as Klein's technique pronounces, the process of determining what counts as a problem - a site of injury or damage in need of repair - is perhaps one of the most ethically fraught aspects of the analytic process since it is always bound up with deciding who has the authority to adjudicate it. The fact of the child-patient only intensifies the potentially paternalistic dynamic since child-analysts (like parents) are charged with acting in the child's "best interests," as though what qualifies as a "best interest" in any situation, for any object, is objective and pre-given. This is precisely the problematic that child-analyst Adam Phillips means to address when, in his commentary on Judith Butler's theory of melancholia, he queries: "Who, for example, decides what constitutes a problem for the patient? And by what criteria?" As Phillips points out, negotiating this question is a clinical as much as a critical necessity. In this way, the clinical situation with children has an uncanny resonance with reparative reading (especially insofar as it aims to do justice to the object) since many, if not most, of the objects under consideration (texts, films, artworks, social movements, cultural ephemera and debris, textiles, etc.) do not, or are not expected to, speak back. In both situations, the urge to repair or redeem is underwritten by the supposition that, in some way, the object 
needs or wants such curative intervention; only with this mutuality of wills does the (interpretive) address seem other than an identificatory extension of the critic-qua-analyst's own will. In other words, in both the clinic and the humanities the status of interpretation is intricately bound up with a question about the ethics of relationality between subjects and their objects.

Not coincidentally, Klein would come to reflect at great length on the psychic dynamics of processes that strive to "do good" to their objects in this way - that want to heal, repair, help, or cure them - especially as she saw it acted out by her child patients. Indeed, it almost seems as though Klein's thinking about reparative urges in the child functions as a proxy for her own position in the clinic where, as an analyst, she aims to have a curative and reparative effect on the child-patient made ill by a combination of external and internal factors. Yet ironically Klein's thinking about the urge toward reparation says very little about the status of the object as such, a fact that feminist and queer scholars engaging in reparative readings routinely overlook (and we, like Robyn Wiegman, might consider why this is). For Klein, reparation names the child's phantasy not necessarily the object's need. Part of the child's process of making good therefore involves its strategic decision about the object's "best interests," about what counts as an injury for the object, what does not, and about how to best enact repair. As I discuss, this undertaking lands the child squarely in the terrain of the ethico-political and enmeshes it in the often-obscured violence that produces and structures such a field. Klein suggests not just the extent to which interpretation might be central to curative endeavors, but also showcases the fact that projects geared toward reparation — be they clinical, critical, or political — are not outside of the circuits of violence and attack; that the very imperative to repair can, in fact, be violent. As I contend, Klein's clinical writings speak to the ethical complexity of reparative projects, which charge themselves not only with the authority to delimit injury but also to select (and exclude) the always already political objects worthy of repair in the first place. In what follows, I attend to how these ethical concerns play out in Klein's case study about a child named "Richard" who she analyzed during World War II and whose political play demonstrated, for Klein, the operations of depressive reparation that she was just beginning to theorize. 


\section{Mrs. K, Richard, and "The Bad Hitler-Penis"}

At the height World War II, Melanie Klein escaped the daily London blitzkrieg by fleeing to the safety of Pitlochry, a town in the Scottish countryside where she resided for most of 1941. Many British analysts (and naturalized citizens, like Klein) sought refuge in this way since a local relocation allowed them to maintain small practices away from the most dangerous incursions of the war. Unlike the British, Viennese and other European refugees could not obtain the travel permits necessary to leave London and so were forced to remain in the city throughout the air raids. Holed up in Scotland, Klein saw a limited number of patients and devoted her spare time to making copious notes on one ten-year-old boy in particular. She intended these notes to come together in the form of a book on clinical technique, an aspiration that was not realized until fifteen years later when she returned to her notes, edited them, and compiled a complete case history for a single child-patient named "Richard." Remarking on this process, Klein wrote to fellow child-analyst, D.W. Winnicott on May $30^{\text {th }} 1941$ : "I have started the analysis of a very unusual boy of ten a month ago \& keep full notes including my interpretations from this case. It takes me $1 \frac{1}{2}-2$ hours a day to make these notes, - a drag but well worth while. ...It really gives me pleasure to think what a good paper this should make" (qtd. Grosskurth, 262). Klein worked on this "good paper" from 1956 until her death in 1960 and Narrative of a Child Analysis was published posthumously a year later. At just shy of 500 pages it is the longest case history ever recorded. It details the almost daily sessions (the text includes 93 sessions, but Klein's diary lists 96) that Klein conducted with Richard over the course of four months. Each session narrates Richard's speech, mood, actions, and play, followed by Klein's own interpretations as she spoke them, live time, to Richard. Composed more like a 93 act play than a scientific treatise, poet Henry Reed quipped that Narrative of a Child Analysis stood beside War and Peace on his bookshelf, a fitting location given its martial drama.

According to Klein's introduction, when Richard first came for treatment he had been struggling with severe anxieties and phobias for two years, since the outbreak of the war in 1939. He was terrified of other children, unable to attend school, hypochondrical, inhibited in learning, and frequently subject to depression (1961, pg.15). In his family life, he was the younger of two children. While he still lived with 
his father and mother, his older brother had enlisted in the war and was only home on temporary leave. Although Klein observed that he had "precocious" artistic sensibilities and a great love of nature and music, these interests were often stifled by his anxious concern for his mother's wellbeing, his paranoid fear of other children, and his obsessive interest in the daily developments of the war. Every day he read four newspapers, listened to the radio for progressive updates about the war, and fervently tracked Hitler's advance across the continent. When, at the outset of their first session, Klein asked Richard to discuss some of the "difficulties" that caused him to be brought in for analysis, what Richard gave by way of explanation was an expansive description of national conflicts:

He also thought much about the war. Of course he knew that the Allies were going to win and was not particularly worried, but was it not awful what Hitler did to people, particularly the terrible things he did to the Poles? Did he mean to do the same over here? But he, Richard, felt confident that Hitler would be beaten. (When speaking about Hitler he went to have a look at the large map hanging on the wall.) ... Mrs. K was Austrian, wasn't she? Hitler had been awful to the Austrians though he was Austrian himself... (1961, pg.19-20)

Throughout the course of the analysis, Richard would continue to bring the political events occurring throughout Europe into his daily psychoanalytic sessions. In his drawings, in his play, and in his speech, he detailed the progression of the war and acted out everything from The Battle of Crete and the naval expeditions of the warships Bismarck and Nelson to Switzerland's precarious neutrality and Germany's gluttonous expansion. He brought his own set of toy battleships with him to most sessions and used the art supplies that Klein provided to create dozens of drawings that depicted air, sea, and railway attack as well as the constantly shifting national borders and alliances of what he called "The Empire." World War II, particularly as it was epitomized by the conflict between Hitler's Germany as a singular "bad" and the British as a collective "good," was the subject of almost all of Richard's concerns throughout his treatment. 
Although it might seem hardly surprising that a child in 1941 whose brother was enlisted in the British Army and whose house in London had already been bombed would be preoccupied by world events, for Klein this persistent interest in conflict, destruction, attack, and Hitler himself bespoke the internal—rather than external—dynamics of attack and repair. Klein interpreted Richard's keen interest in international political conflict as a symptomatic projection of a deeper and more fundamental psychic conflict. In her efforts to alleviate Richard's anxiety and palliate his symptoms, Klein's interpretations throughout these sessions ceaselessly returned to what she read as the organizing figures of Richard's psychic life. When Richard talked about battleships, Hitler, and national alliance, Klein rejoined with the threats posed by Daddy's "bad Hitler-penis," Mummy's positioned body, and the copulating "combined parent” figure. Although Richard often disagreed with these interpretations and responded with strong anxiety, Klein persisted. Klein's interpretive panache is dramatized in Richard's third session when he returns to the map on the wall (which he had noticed in the first session) and speculates about national conflict and alliance.

He soon turned to the map and expressed his fears about the British battleships being blockaded in the Mediterranean if Gibraltar were taken by the Germans. They could not get through Suez. He also spoke of injured soldiers and showed some anxiety about their fate. He wondered how the British troops could be rescued from Greece. What would Hitler do to the Greeks; would he enslave them? Looking at the map, he said with concern that Portugal was a very small country compared with big Germany, and would be overcome by Hitler. He mentioned Norway, about whose attitude he was doubtful, though it might not prove to be a bad ally after all.

Mrs $K$. interpreted that he also worried unconsciously about what might happen to Daddy when he put his genital into Mummy. Daddy might not be able to get out of Mummy's inside and would be caught there, like the ships in the Mediterranean. This also applied to the troops which had to be retrieved from Greece. (1961,pg.28) 
Richard's anxieties, as he expresses them, have to do with the political topography of Europe: ships stranded in the Mediterranean might not be able to get their wounded soldiers to allied soil in time to save their lives; Greek citizens recently conquered in The Battle of Greece might be enslaved — or worse — by advancing Nazi soldiers under Hitler's command; Portugal, relatively small and neighboring fascist Spain, could easily be "overcome." But for Klein the realist purchase of these concerns has little appeal and she interprets Richard's worries as traces of his unconscious phantasies, which are projected onto external events. For instance, Richard's fear of Hitler as an aggressive and subjugating force represents his anxiety about his "Daddy's" alternately helpful and harmful penis. "Mummy," here figured as the vast expanse of earth and ocean on which this military drama was being literally mapped out, could engulf and capture the "good" father-penis, represented by the British warships. The idioms of 'Father of a Nation' and 'Mother Earth' are taken quite literally in Klein's interpretation, which proposes that familial and (hetero)sexual symbols are the deepest and most determinative objects for the child psyche. ${ }^{6}$ Put another way, Richard's interest in war indexes his internal conflict, the war inside.

Although it would appear that Klein is, time and again, ahistorically returning Richard's political anxieties to an ever-present "Mommy-Daddy-Me" triangulation that privileges the European middleclass nuclear family as the seat of all psychic life, in this very gesture she actually remobilizes much of the historically specific war vocabulary that saturated 1940s discourse in Britain. Watching Richard play with the toy battleships he often brought to his sessions, "Mrs. K." routes the grammar of war that animated Richard's manipulation of the ships from his external world to his internal one. Plagued by the wish to "kill," "blow up," "ambush," "bomb" and "attack" the "hostile" persecutors who appear allied against him, the relations that characterize Richard's unconscious phantasies have much in common with

\footnotetext{
${ }^{6}$ Throughout Klein's oeuvre, she is persistent in her conviction that "mental health" is demonstrated by genital heterosexuality. For examples of this, see cases like "Mr. B," "Erna," "Rita," "Little Dick" and "Richard." Ramon E. Soto-Crespo argues creatively and persuasively for a reading of Klein's work that challenges her hetero-normativity and her understanding of an anatomically grounded sexual difference by focusing on the life-worlds of the child's unconscious phantasies. However, at the level of Klein's interpretive presence in the clinic, she consistently privileges genital heterosexuality. For Soto-Crespo's re-reading, see "Heterosexuality Terminable or Interminable? Kleinian Fantasies of Reparation and Mourning" in Homosexuality and Psychoanalysis (2001).
} 
international relations during the war. Klein does not date each of the sessions in the text of Narrative, but her pocket book records that Richard's analysis lasted from April $28^{\text {th }}$ to August $23^{\text {rd }}$ of 1941 , a time span that witnessed the continued bombing of Northern Ireland, the fall of Greece, the sinking of the Bismarck, the invasion of the Soviet Union, and perhaps most notably the bizarre arrival of Rudolf Hess, Hitler's second in command, who fled Germany in the middle of the night and bailed out over Glasgow, less than 100 miles from Klein, seeking asylum. ${ }^{7}$ From a historical perspective, then, Klein constructs her instinctual, phylogenetic unconscious on and through modern European political conflict narratives, emblemized in the swing between aggressive "attack" and amelioratory "reparation." During a time of attacks, bombings, and invasions, followed by monetary reparations, Klein's interest is not in the purchase of these phenomena in the external world but rather the way they organize the psychic life of children. ${ }^{8}$ Essentially, Klein takes the political discourse of World War II and maps in onto- and intothe mind of the child. For Klein, children's play is nothing more or less than international war games.

Although Klein had often discussed the infant's aggressive, paranoid-schizoid orientation to the world, it was not until her watershed 1935 paper, "A Contribution to the Psychogenesis of Manic Depressive States," that she solidified a second "depressive" position and proposed "reparation" (which she had also previously called "restoration") as its primary process. Klein thus interpreted Richard's case a demonstration of the two psychic positions, paranoid-schizoid and depressive, that she had just begun to theorize a few years before. In the paranoid-schizoid position, which Klein imagines organizes the earliest experiences of the child's postnatal life, the child negotiates the excess of physical stimulation and instinctual need through processes of "splitting" and "projection." Since the child is confronted by complex sensations that it does not yet have the psychological sophistication to process, the child splits

\footnotetext{
${ }^{7}$ For a fascinating historical account of Rudolf Hess's role in the wartime psychoanalytic work that sought to understand "Nazi psychology," see The Pursuit of the Nazi Mind by Daniel Pick (2012). Pick does not explore the coincidence of "asylum" that was motoring Hess's escape, but his desire for political refuge through an appeal to psychological malady is certainly noteworthy.

${ }^{8}$ For further analysis of this, see "The Hitler Inside: Klein and Her Patients" in Michal Shapira's The War Inside: Psychoanalysis, Total War, and the Making of the Democratic Self in Postwar Britain (2013).
} 
the experiences into monolithic units_-"good" and "bad"—-and projects them into the external world. Its experience of being fed when hungry, for example, is projected onto the "good" external breast which it loves, whereas its experience of being left hungry is projected onto the "bad" external breast, which the child experiences as hostile and aggressive, literally attacking the child and causing the pain of hunger. Hence, "projection" and "splitting" allow the child to cope with its own conflicted instincts and environment by reducing their affective complexity and expelling them to safe distances. Working in tandem, these processes define the child's first relations to the social world, which it perceives as dangerous and persecutory.

From a historical perspective, the fact that Klein began to elaborate a turn from the paranoidschizoid to the depressive position in the 1930s is anything but insignificant since the interwar years in Britain witnessed some of the most fervent public debate about the propriety and justness of material reparations after Germany's defeat in World War I. Although public opinion about reparations during World War I was divided, in the years after the Treaty of Versailles the bloodlust for German reparations lost its glowing appeal, in large part because of the publication of John Maynard Keynes's The Economic Consequences of Peace (1919), which became an immediate, trans-Atlantic bestseller. ${ }^{9}$ In it, Keynes forcefully admonished the architects of The Treaty of Versailles and reproved the Treaty's mandates about reparations on economic and political grounds, calling the treaty a "Carthaginian Peace." What Keynes suggested - and not unfoundedly so - was that the reparations claims were a form of fiscal punishment meant to chasten Germany for its bellicosity: the Germans had taken their pound of flesh throughout the war and they were to pay it back afterward in pounds of gold. Keynes's text, perhaps more than any other single document, brought about the widespread public opinion that the Allies had mistreated Germany and that such unrealistic reparations were the primary seat of this ill-usage. Given this anything but glowing political history, it is interesting that during the very years when this term

\footnotetext{
${ }^{9}$ For further reading on the public policy debate among Allied countries about German reparations, see Brunselmeyer, The Cost of War, 1914-1919 and Kent, The Spoils of War.
} 
carried the strongest political distaste Klein would mobilize it to name what she described as the most ethical position of which the child was capable. Regardless of whether or not Klein had either of these political uses of the term in mind when she theorized the way that attack and reparation structure the mind of the child, her ability to even think the subject along the lines of reparation testifies to the broader conception of postwar justice enabling her theory. Read in this context, the grammar of individual psychological repair emerges in connection with what appear to be clear and identifiable historical aggressions in international war. Faced with the failures of reparations on an international scale, Klein's clinical work comes to light as a fraught grappling with a crisis of European thinking about the possibility of justice. Read charitably, Klein's appropriation of a reparative ethics in the clinic can be seen to signal a resilient hope for a form of justice that had just been proven untenable in world politics.

Understandably, then, Richard's case in 1941 arrived a pivotal moment in the conjuncture between Klein's theory of psychic life and the history of modern European conflict and justice. Klein interpreted Richard's case as the most compelling demonstration of the reparative impulses characteristic to the depressive position. Included in his case are Klein's appended notes from her editorial revisions in the late 1950s, which repeatedly draw the reader's attention to how these reparative tendencies were at work in Richard. For instance, after session seventy-one when Richard had enacted a "disaster" with toy trains that were bombed on their way to London (where Klein herself was preparing to travel), Klein writes that

there was also, together with the facing and expression of these various anxieties, a diminution of the violence of his [Richard's] destructive impulses. The cautious and anxious way in which he took the toys out of the bag and in which he decided that the damaged figures would have to go to hospital—asking me at the same time to mend the boy figure who represented himself - shows how both hope and the urge for reparation were operative side by side with his anxieties. ... When destructive impulses and their consequences come closer together with a revived capacity for love and are mitigated by it, they become less overwhelming and reparation becomes possible... (1961, pg.366-67) 
Richard's care with the toys, his assessment of their damage, and his investment in having them "mend[ed]" by Klein and the "hospital" indexes for Klein his "urge for reparation." As Richard's case progressed, Klein increasingly interpreted the reparative tendencies animating Richard's play, concluding (as she does here) that Richard was in the process of integrating his life and death instincts, a vital step for Klein's understanding of analytic success. This passage highlights how Richard's urge to repair the toys is based on his own delineation of their damage — he decided the perimeters of their injury and proposed a course of treatment based on his own investment in his creative and reparative capacities. First identifying with the agent of attack — the Hitler inside - Richard then comes to identify with the attacked toys, constantly oscillating between the two object relational positions of identification.

A long passage from Richard's twenty-fourth session shows this oscillation and hence the interaction between attack and repair.

Richard had in the meantime been all round the room, exploring, looking into books, and finding things on the shelves. He repeatedly touched Mrs K.'s bag, obviously wishing to open and examine it. He squeezed a little ball between his feet and then began to do the goose-step, saying what a silly way of marching it was.

$\operatorname{Mrs} \mathrm{K}$. interpreted that the little ball represented the world; Mummy and Mrs K., squeezed by German boots - the goose-step. In doing this Richard expressed his feeling that he not only contained the good Mummy but also the Hitler-father, and was destroying Mummy as the bad father did.

Richard strongly objected, saying that he was not like Hitler, but he seemed to understand that the goose-stepping and the squeezing feet represented this. It was nearly time to go and Richard become very friendly and affectionate. ...He asked her [Mrs K] to be silent, held his breath, and said, 'Poor old room, so silent.' Then he asked Mrs K. what she was going to do over the weekend.

Mrs $K$. interpreted his fear that she might die at the weekend - the poor old silent room. That was why he had to make sure about her bringing the drawings; this also 
expressed his wish to help in the analysis, and thus to put Mrs $K$. right and preserve her. This was why he wished for Mrs K. - the poor old radiator- to have a rest, not to be exhausted by her patients, particularly by him. (1961, pg.114)

In the first half of this passage, Richard plays at the military goose-step while Klein interprets (much to Richard's dismay) his aggressive identification with the bad Hitler-father bent on destroying the good Mummy-world. This aggressive attack is then followed by Richard's reparative concern in the second half of the passage for the consulting room, which represented Klein and registered his worry that she might "die at the weekend" because of his goose-stepping assaults. After trying to squash "Mrs K." under his heel, Richard feels guilty about his attempted murder and grows concerned for the survival of the room, the analysis, and Klein herself.

According to Klein's interpretations here, the depressive position follows on the coattails of the paranoid-schizoid position and involves the child's experience of guilt, love, creativity, and the impulse to repair. Whereas in the paranoid-schizoid position the child attacked unadulterated "good" and "bad" part objects (the archetype of which is the breast), in the depressive position the infant becomes aware that the attacked breast is the same as the "good" feeding breast that provides warmth and comfort and therefore that its destructive onslaught aimed also at a loved and cherished object necessary to the infant's survival. The infant, phantasizing its paranoid attacks to be the cause of damage to the now-loved whole object, identifies with the object and attempts repair.

If the baby has, in his aggressive phantasies, injured his mother by biting and tearing her up, he may soon build up phantasies that he is putting the bits together again and repairing her. This, however, does not quite do away with his fears of having destroyed the object which, as we know, is the one whom he loves and needs most, and on whom he is dependent. In my view, these basic conflicts profoundly influence the course and the force of the emotional lives of grown-up individuals. (1937, pg.308-09)

The depressive position is thus marked by the infant's experience of ambivalent "whole objects," which it understands itself capable of injuring and even losing, prompting a mournful or "pining" attitude. But in 
order to offer reparation, the infant must first decide that an object is worth saving, a point whose political consequences David Eng has trenchantly unpacked in his article "Colonial Object Relations.” As Eng writes, "we might go so far as to say that the object chosen for repair is not only constituted as good and worthy of reparation but also psychically constituted as human" (126). Eng's point has to do with the significant number of racialized objects excluded from reparative calculations and how they index colonialism's determinative role in the distribution of morality and affect. To this valuable insight, I would also add, however, that in Klein's framework even the process of recognizing an other in no way safeguards an ethical relation since this recognition is based on an identification that ascribes the other an injury — a site of damage or harm—only as a means to assuage guilt. Indeed, the fact of the object's "humanity" seems important only insofar as the child can interpret it as human "like me," damaged—and reparable - according to its own imposed narrative.

Put another way, the reparative gestures that Klein is describing in the depressive position happen at the level of the child's phantasy and thus are about how the child perceives itself in relation to its object, rather than about the state of the object itself. Depressive reparation, for Klein, is based on the child's ability to form an identification with a whole-object, casting itself into the place of the object under siege and becoming aware of the vulnerability of the other precisely on and through the contours of the child's own self. In her "Final Remarks" on Richard's case, Klein concludes with the importance of reparation: "I have referred to the fact that Richard, who so strongly hated the enemies threatening Britain's existence at that time, became capable of feeling sympathy for the destroyed enemy. This was shown, for instance, when he regretted the damage done to Berlin and Munich and, at another occasion, when he became identified with the sunk Prinz Eugen" (1961, emphasis added,pg.466). Although scholars reading through a "reparative" idiom do not frequently mention this, Klein is insistent that the depressive position and reparation derive from the child's ability to put itself in the object's place, scripting the object's injury according to the perimeters of its own guilt. Klein alternately describes this as "true reparation," "genuine sympathy," or "authentic sympathy," all terms that speak to the self-other identification at the heart of reparative relations (1937, pg.66). Indeed, in a public lecture Klein gave, she 
explicitly listed reparativity under the subheading "Identification and Making Reparation," explaining (again through the language of authenticity) that " $[\mathrm{t}] \mathrm{o}$ be genuinely considerate implies that we can put ourselves in the place of other people: we can 'identify' ourselves with them... [this is] a condition for real and strong feelings of love" (ibid). Whereas Klein writes constantly about how reparative tendencies aim to love the object, to ameliorate harm, to repair injury, and to generally "make good," Klein means this language to describe the child subject's own affective climate in relation to the object world. Reparativity is important in Klein's psychodynamic theory not because it constitutes an ethical relation to the world per se-there is no guarantee that its intentions to "do good" translate in any way to material consequences, or that the objects of one's reparative intentions are politically desirable — but because it gives the child the feeling of ethical action and thereby allows it to expiate its own guilt and reinvest the world of object relations.

As might be clear from the language of authenticity, Klein's work, like Sedgwick's, ascribes this object-orientation a moral weight, narrating its operation as less violent and destructive than its "paranoid" sibling. But it is precisely the ethical status of reparation, especially as enacted by identification, on which I want to pause. In Klein's endnotes, when she reflects on the case and considers the beneficial effects of the analysis, she marks Richard's progress by his ability to sympathize, to identify with, the "destroyed enemy." Klein downplays the political implications of this assessment by naming cities as the objects of Richard's sympathy and by highlighting (from her editorial postwar position in the 1950s) that it was "the [fascist] enemy" who was "destroyed," thereby lending Richard's sympathy the air of magnanimity. Taken from a different angle, however, what Klein suggests here is nothing less than that Richard's ethical achievement is shown by his identification with Nazi Germany at the height of a genocidal extermination. Richard's progress is signified by his ability to see himself in a fascist, anti-Semitic empire.

Hence, for Klein, the supposedly ethical aspect of reparation - a term not unburdened by the history of state wars and genocidal logics - is the child's self-sustaining identifications, which exculpate its own guilt by adjudicating injury and repair. In this process, the child constructs the object's injury 
according to its own expectations and desires, its own ability to position itself as the agent of repair. This is a process undertaken with little attention to the ethical pitfalls of identification (which derive from the recognition and reproduction of similitude) or of the political consequences of the particular objects both taken up and cast aside. My closing question is therefore a simple one: what picture of reparation do we get if we shift the focus from the child's own good feeling to the ethical status of identification and the political life of its objects?

\section{Beyond Repair?: Identification, Ethics, and the Limits of Reparative Reading}

Lauren Berlant, writing about Eve Sedgwick and the desires that animate and sustain our attachment to the world even (and perhaps most especially) in affective climates that constantly thwart us, asks in passing a similar question about the ethics of reparative practice as the one I have been raising here. "I love the idea of reparative reading," begins Berlant, "insofar as it is a practice of meticulous curiosity. But I also resist idealizing, even implicitly, any program of better thought or reading. How would we know when the 'repair' we intend is not another form of narcissism or smothering will? Just because we sense it to be so?” (2011, pg.124). Berlant does not engage with Klein's work when she poses these questions about the limits and effects of repair, nor does she follow them through to any substantial ethical or political conclusion, but in these few lines she already suggests the dangers attending the identificatory undercurrents of reparative programs. How indeed can we — critically, clinically_ disentangle the desire to act on the object's behalf from our own ideological investment in what their behalf is or ought to be (as though the descriptive and the prescriptive were ever separable to begin with)?

In her own analysis, Robyn Wiegman elaborates precisely this point by directing attention to how reparative reading works to sustain not the object but the critic, rewriting "the critic's value as the consequence of the object's need" (2014, pg.16). Taking the oft-forgotten publication history of Sedgwick's essay (which first appeared almost a decade before it was published in 2003) as her springboard, Wiegman interrogates the present tense desires motivating the widespread turn to a method that promises to love and care for its objects of study. Wiegman's conclusion is similar to my own in that 
she highlights how the needs of the critic are paramount in the relation of repair, suggesting that reparative reading is a critical strategy for reinvesting in and reattaching to the promise of interpretation during times of economic and institutional precarity. Far from acting in service of the object, Wiegman argues that at a time of institutional crisis in the interpretive humanities, reparative reading works as a way for queer and feminist scholars to sustain their own sense of purpose, relevance, and value in a hostile environment that may, terrifyingly, be of their own making. The repair offered is thus much more to do with the critic's own sense of self, own self-image, than with the needs of the object.

I agree with much of Wiegman's analysis, but while her primary interest is in the current political and institutional contexts motoring queer and feminist desires for a nondestructive, nonaggressive critical method that nurtures the object, my own analysis has less to do with situating the origins of these desires than it does with speculating about their means and their effects, disarticulating the reparative intention from the ethical and political effects of such an imperative. Far from offering a corrective to Sedgwick's reading of Klein, then — a point that seems rather fruitless given that the status of interpretation itself is the issue at hand-I am concerned with the ethico-political dangers of a method that downgrades the potential violence of defining injury and ascribing repair, be it with children, texts, movements, populations, art objects, or concepts. This potential violence is far from abstract and is materialized quite plainly in a public lecture that Klein delivered at Caxon Hall in London, one of her few public engagements. In this lecture, which she gave with Joan Riviere, Klein offers a rare social example intended to illustrate, for her audience, the clinical concept of reparation.

The child's early aggression stimulated by the drive to restore and to make good, to put back into his mother the good things he had robbed from her in phantasy, and these wishes to make good merge into the later drive to explore, for by finding new land the explorer gives something to the world at large and to a number of people in particular. In his pursuit the explorer actually gives expression to both aggression and the drive to reparation. We know that in discovering a new country aggression is made use of in the struggle with the elements, and in over-coming difficulties of all kinds. But sometimes aggression is shown 
more openly; especially was this so in former times when ruthless cruelty against native populations was displayed by people who not only explored, but conquered and colonized. Some of the early phantasied attacks against the imaginary babies in the mother's body, and actual hatred against new-born brothers and sisters, were here expressed in reality by the attitude towards the natives. The wished for restoration, however, found full expression in repopulating the country with people of their own nationality. (1937, pg.334)

Taking the scene of colonial conquest as her object—and making sure her 1936 British audience knows that all of this happened in "former times" rather than their own political present—Klein literally maps the paranoid-schizoid and depressive positions onto the history of (ostensibly Western) colonial invasion, subjugation, and extermination. While the invasion of foreign lands and the slaughter of "native populations" is a clear display of the infant's hostile attacks on its mother's body (again figured as the world), Klein (somewhat unbelievably) argues that the "repopulate[ion]" of the ravaged country by the colonist's own people constitutes reparation, the ethical ideal. Read from this vantage, colonial repopulation is a demonstration of the "creativity" of a conqueror's response to his or her own decimation of indigenous peoples.

David Eng comments on this passage, noting how this vision of reparation enters into an established liberal narrative of retroactive justice for past histories of colonial violence and exploitation that naturalize love as the "property of the European liberal human subject, foreclosing in the process any possibility for racial reparation and redress" (2016, pg.14). Read in this context, the vocabulary of reparative justice emerges in connection with (and seems inextricable from) the grammar of state injustices that propose the tidy closure of past aggressions by the state's liberal promise of fiscal compensation for physical violence. This more sinister geopolitical reading of reparations suggests, according to Eng, that even deciding which objects count as objects deserving of repair is already a political calculus inseparable from national histories of oppression and subjection. But my own point is that if the "native populations" massacred by the "ruthless cruelty" of imperial conquest do not even register as a loss, it is only because the identificatory optics of reparation script injury according to their 
own (colonial) desires. The injury of colonial aggression is registered only as depopulation, an assessment that is stubbornly insensible to the racial and national politics enabling such an event. Given this (reparative) logic, repopulation seems a natural (indeed, "ethical”) solution. Yet, as most readers can clearly recognize, this calculation is a strategic one that refuses to account for the violence produced by the identificatory relation mobilizing it or the political consequences of its enactment. Neither Richard's reparative sympathy for Nazi Germany nor the explorer's colonial repopulation take into account the particular political status of the object being offered reparation, nor do they weigh the ethical hazards of such identificatory relations in the first place.

To give but one final instance of the disquieting underside of such reparative responses, in another piece of cultural analysis Klein analyzes a woman's sudden desire to paint — her need to fill the empty hole on her wall — as an instance of maternal reparation, willfully blind to the what she includes as merely the incidental fact that the image painted in this "blank space" was the body of a "naked negress" (Klein, 1929, pg.215;217). Klein turns to the story of this painter, who she names "Ruth Kjar" (but who is likely Ruth Weber), as an example of what Klein calls "true reparation," a form of authentic ethical action from which creativity is born. ${ }^{10}$ Yet, much like her colonial expedition, Klein's reading of the painter's reparative impulse is unconcerned with the racialized body count that her reparative efforts leave in their wake. For certainly the "naked negress's" occupation of the blank space is far from the first time that black women's bodies have been appropriated to slake the emotional needs of white women under the auspices of care. Here, the "injury" is the "empty wall" and the painter's own internal sense of emptiness, not the frivolous decorative appropriation of racialized femininity. Klein considers reparation to name only the subject's ability to sustain itself through "creative" action, where "creativity" can just as easily present as Nazi sympathy, colonial "repopulation," or the continued aesthetic fetishization of the "naked negress." Read from a political angle, this ethic of creativity begins to seem more than a little destructive.

\footnotetext{
${ }^{10}$ For a consideration of the painter's identity, see "Depression and Reparation as Themes in Melanie Klein's Analysis of the Painter Ruth Weber" in The Scandinavian Psychoanalytic Review 27.1 (2004). 
I will be the first to admit that, in making this argument, I am drawing parallels between a diverse set of reparative experiences. Without doubt, a midcentury boy's games with wooden toys have entirely different lived consequences than the centuries-long atrocities that were a part of colonialism's “civilizing" mission. In this same way, I know that clinical psychotherapies that operate under the sign of the reparative (either from Kleinian or post-Kleinian orientations) are functioning with a significantly different imperative - and with significantly different challenges and risks - than critics in the humanities exploring the reparative as an alternate methodology. Not all instances of identification produce dangerous or damaging results; Richard's passing remorse for destroyed toy Nazi cities hardly led him to subsequently align himself with National Socialist or Neo-Nazi platforms. As the means to social attachment, identification can unequivocally create sustaining and politically productive social bonds. My intention here is not to flatten out these important distinctions, even as I also know that analogy's political strength is its ability to pronounce comparative similarities while eliding often-important individual particularities. Rather, by arraying my own objects in this unabashedly critical fashion, what I am trying to emphasize is the indispensability of the work of critical interrogation that strives, however impossibly, to move beyond the subject's own feeling of just or righteous action. I am all for good intentions, all for an eye toward justice whenever and wherever possible, so long as that subjective intentionality is counterbalanced by an unsentimentalized political (and even historical) analysis of how those intentions often engender far-reaching effects that complicate the ethical status of the original intent. In other words, mine is an argument that puts pressure on Klein's binary thinking about "true" and "false," "authentic" and "inauthentic" reparation by considering how a critical eye trained on political and historical distributions of power invariably complicates the ethical purity of any subject's psychic positionality.

As a note in closing, I might add that I do not mean to suggest that the properly ethical solution to this dynamic is to defer the assessment of injury or damage to the object itself (assuming we are speaking about an other), as though one's ability to speak on one's own behalf is somehow less ethically fraught than one's willingness to speak on behalf of another. From the vantage of the unconscious, both alternatives find their fault in the (neo)liberal fantasy of a fully conscious rational agent. Rather, I simply 
want to put pressure on methods that depoliticize processes of constituting injury and repair and in so doing render them ethically ideal. Indeed, I am brought to wonder through this writing about the utility of thinking in terms of an injury/repair framework in the first place since my sense is that such a narrative always enforces, however subtly, a normative ideal of health, wholeness, and wellbeing. When it comes to a reparative mindset, either in critical practice or in the clinic, I might just suggest that there is no guarantee that even the most well-intentioned object relations will be anything more than yet another colonization of the object's mind. Given this, I wonder if there might not be some ethical value in a methodological orientation that considers, from the beginning, that a past of violent destruction cannot and should not be redeemed, is importantly beyond repair. The question becomes: what then? 


\begin{abstract}
This paper puts clinical child psychoanalysis into conversation with recent debates about critical method in order to question the turn toward so-called "reparative reading" in feminist and queer theory. While Eve Kosofsky Sedgwick's original call for a new kind of reparative method culled its key terms ("reparative" and "paranoid") from child psychoanalyst Melanie Klein, the scholars who have adopted reparativity in critical theory pay little attention to Klein's work. In this paper, I take up Klein's theory of the depressive position and reparativity as she elaborated them in her clinical work with children, particularly her wartime analysis of "Richard" in 1941. Klein interpreted Richard's play — his clinical "war games" - through her idiomatic vocabulary of "attack" and "repair." By situating this case and Klein's larger theory of psychic reparations in the political climate of wartime Europe, I argue that Klein's writings point to the ethico-political dangers inherent in reparative endeavors, which name the object and narrate its injury and repair according only to the perimeters of one's own self. From this reading, I propose that there might be a benefit to foregoing the injury/repair framework implicit in reparative agendas - both critical and clinical alike. By returning reparativity to Klein, I therefore aim not to offer a corrective to Sedgwick or to the scholars following her, but rather to interrogate the ethical stakes of all reparative endeavors, be they political, intellectual, or clinical. At the most basic level, then, this paper argues that the space of the clinic is an important (and often undervalued) object for the consideration of critical method.
\end{abstract}

\title{
Key Terms
}

Reparative Reading; Melanie Klein; Child Psychoanalysis; Clinical Ethics; Queer and Feminist Theory; Interpretation

\section{Biography}

CAROLYN LAUBENDER, Ph.D. is a Lecturer in the Department of Psychosocial and Psychoanalytic Studies at Essex University. Her writing has appeared in Psychoanalysis and History, Feminist Theory, Journal of International Women's Studies, and Harts \& Minds: The Journal of Humanities and Arts. Her current project, The Child in Mind: Psychoanalysis, Politics, and the Clinic, theorizes how the child psychoanalytic clinic became a site of experimental political action throughout Europe in the twentieth century. 


\section{Works Cited}

Berlant, Lauren. Cruel Optimism. Durham: Duke University Press, 2011.

Britzman, Deborah. After-Education: Anna Freud, Melanie Klein, and Psychoanalytic Histories of Learning. New York: New York State University Press, 2003.

- Melanie Klein: Early Analysis, Play, and the Question of Freedom. London: Springer Press, 2016.

Bunselmeyer, Robert E. The Cost of War, 1914-1919: British Economic War Aims and the Origins of Reparation. Hamden, CN: The Shoe String Press, 1975.

Cvetkovitch, Ann. Depression: A Public Feeling. Durham: Duke University Press, 2012.

Eng, David. “Colonial Object Relations.” Social Text, vol. 34, num. 1 126, 2016: 1-19

Felman, Shoshana The Scandal of the Speaking Body: Don Juan with J.L. Austen, or Seduction in Two Languages. Stanford CA: Stanford University Press, 2002.

Felski, Rita. "Introduction,” New Literary History 45.2 (2014): v-xi

Freeman, Elizabeth. Time Binds: Queer Temporalities, Queer Histories. Durham, Duke University Press, 2010.

Freud, Anna. Four Lectures on Child Analysis (1927). The Writings of Anna Freud, Vol I. New York: International Universities Press, 1974.

Grosskurth, Phyllis. Melanie Klein: Her World and Her Work. London: Jason Aronson Inc, 1986.

Hanson, Ellis. "The Future's Eve: Reparative Reading after Sedgwick.” South Atlantic Quarterly, vol. 110, num. 1, 2011: 101-119.

Hemmings, Clare. “The Materials of Reparation.” Feminist Theory, vol. 15, no. 1. 2014: 27-30.

Hinshelwood Robert D. A Dictionary of Kleinian Thought. London: Free Association Books, 1998.

Isaacs, Susan. "On The Nature and Function of Phantasy" [1943], International Journal of Psychoanalysis 29 (1948): 73-97.

Kent, Bruce. The Spoils of War: Politics, Economics and the Diplomacy of Reparations 19181932. Oxford: Claredon Press, 1992.

King, Pearl and Ricardo Steiner, eds. The Freud-Klein Controversies: 1941-45. London:

Tavistock/Routledge, 1991.

Klein, Melanie. "The Psychological Principles of Early Analysis (1926)." Love, Guilt, and Reparation and Other Works 1921-1945. New York: The Free Press, 1975. 128-138.

— "Criminal Tendencies in Normal Children (1927)." Love, Guilt, and Reparation and Other Works 1921-1945. New York: The Free Press, 1975. 170-185. 
— "Infantile Anxiety-Situations Reflected in a Work of Art and in the Creative Impulse (1929)." Love, Guilt, and Reparation and Other Works 1921-1945. New York: The Free Press, 1975. 210-218.

- The Psycho-Analysis of Children (1932). London: Vintage, 1975.

- "Love, Guilt and Reparation (1937)." Love, Guilt, and Reparation and Other Works 1921-1945. New York: The Free Press, 1975. 306-343.

- Narrative of a Child Analysis: The Conduct of the Psycho-analysis of Children as Seen in the Treatment of a Ten-Year Old Boy (1961). London: Random House Press, 1998.

Lewis, Gail. "Not by Criticality Alone.” Feminist Theory, vol. 15, no. 1. 2014: 31-38.

Love, Heather. Feeling Backward: Loss and the Politics of Queer History. Boston: Harvard University Press, 2007.

Meltzer, Donald. The Kleinian Development. London: Karnac Books, 1998.

Munñoz, José. "The Vulnerability Artist: Nao Bustamante and the Sad Beauty of Reparation." Women \& Performance: A Journal of Feminist Theory. Vol. 16 2006: 191-200.

Olsen, Andkjaer Ole. "Depression and Reparation as Themes in Melanie Klein's Analysis of the Painter Ruth Weber.” The Scandinavian Psychoanalytic Review vol. 27, num. 12004.

Phillips, Adam. "Keeping It Moving: Commentary on Judith Butler's 'Melancholy Gender/Refused Identification'." The Psychic Life of Power: Theories in Subjection by Judith Butler. Stanford, CA: Stanford University Press, 1997. 151-159.

Phillips, John and Lyndsey Stonebridge eds. Reading Melanie Klein. London: Routledge, 1998.

Pick, Daniel. The Pursuit of the Nazi Mind: Hitler, Hess, and the Analysts. Oxford: Oxford University Press, 2014.

Rose, Jacqueline. "War in the Nursery," Why War?: Psychoanalysis, Politics, and the Return to Melanie Klein. Oxford: Blackwell UP, 1993. 191-230.

Sedgwick, Eve Kosofsky. "Paranoid Reading and Reparative Reading, Or You're So Paranoid, You Probably Think This Essay Is About You." Touching Feeling: Affect, Pedagogy, Performativity. Durham: Duke University Press, 2003. 123-55.

Shapira, Michal. The War Inside: Psychoanalysis, Total War, and the Making of the Democratic Self in Postwar Britain. Cambridge: Cambridge University Press, 2013.

Soto-Crespo, Ramón. "Heterosexuality Terminable or Interminable? Kleinian Fantasies of Reparation and Mourning," Homosexuality and Psychoanalysis. Chicago: University of Chicago Press, 2001. 190-209.

Stacy, Jackie. "Wishing Away Ambivalence.” Feminist Theory, vol. 15, no. 1. 2014: 39-49.

Wiegman, Robyn. “The Times We're In.” Feminist Theory, vol. 15, no. 1. April 2014. 4-25. 
Wilson, Elizabeth A. Gut Feminism. Durham: Duke University Press, 2015. 